\title{
ON WEIGHTED DISCRETE HARDY'S INEQUALITY FOR NEGATIVE POWER NUMBERS
}

\author{
ALEKSANDRA ČIŽMEŠIJA
}

\begin{abstract}
In this paper we consider the weighted discrete Hardy's inequality for different real power numbers $0 \neq r<1$ and obtain some new refinements of its finite sections. For $r<-1$ our results improve those previously given by Nguyen et al. in $[19,20]$. Moreover, we prove that the constant factors involved in the right-hand sides of the obtained inequalities are the best possible, that is, they cannot be replaced with any smaller constant.
\end{abstract}

Mathematics subject classification (2000): 26D15.

Key words and phrases: Inequalities, Hardy's inequality, strengthened Hardy's inequality, negative power number, weights, the best possible constant, refinements, mixed-means inequality.

\section{REFERENCES}

[1] P. S. BuLLEN, A chapter on inequalities, Math. Medley, 212 (1993), 48-69.

[2] P. S. Bullen, Inequalities due to T. S. Nanjundiah, in: G. V. Milovanović (ed.), Recent progress in inequalities (Niš, 1996), Kluwer Academic Publishers, Dordrecht/Boston/London, 1998, pp. 203-211.

[3] A. ČIžMeŠIJA, J. PEČARIĆ, Mixed means and Hardy's inequality, Math. Inequal. Appl. 14 (1998), 491-506.

[4] A.ČIŽMEŠIJA, J. PEČARIĆ, Classical Hardy's and Carleman's inequalities andmixed means, in: T. M. Rassias (ed.), Survey on Classical Inequalities, Kluwer Academic Publishers, Dordrecht/Boston/London, 2000, pp. 27-65.

[5] A. ČIŽMEŠIJA, J. PEČARIĆ, Some new generalisations of inequalities of Hardy and Levin-Cochran-Lee, Bull. Austral. Math. Soc. 63 (2001), 105-113.

[6] A. ČIŽMEŠIJA, J. PEČARIĆ, AND L.-E. PERSSON, On strengthened weighted Carleman's inequality, Bull. Austral. Math. Soc. 68 (2003), 481-490.

[7] G. H. HARDY, Notes on some points in the integral calculus (51), Messenger of Math. 48 (1919), $107-112$.

[8] G. H. HARDY, Notes on some points in the integral calculus (60), Messenger of Math. 54 (1925), $150-156$.

[9] G. H. HARDY, J. E. LitTLEWOOD, AND G. PólYa, Inequalities, $2^{\text {nd }}$ edition, Cambridge University Press, Cambridge, 1967.

[10] M. JohAnsson, L. E. Persson, AND A. Wedestig, Carleman's inequality - history, proofs and some new generalizations, JIPAM. J. Inequal. Pure and Appl. Math, 4 (2003), no. 3, article 53, 19 pp. (electronic).

[11] S. KAIJSER, L.-E. PersSON, AND A. ÖBERG, On Carleman and Knopp's Inequalities, J. Approx. Theory, 117 (2002), 140-151.

[12] K. KeDlaYA, Proof of a mixed arithmetic-mean, geometric-mean inequality, Amer. Math. Monthly 101 (4) (1994), 355-357.

[13] K. Kedlaya, A weighted mixed-mean inequality, Amer. Math. Monthly 106 (4) (1999), 355-358.

[14] A. Kufner, L.-E. Persson, Weighted Inequalities of Hardy Type, World Scientific Publishing Co., New Jersey/London/Singapore/Hong Kong, 2003.

[15] A. KufneR, L.-E. PersSON, The Hardy Inequality - About its History and Current Status, Research report 6, Dept. of Math., Luleå University of Technology, 2002 (ISSN 1400-4003). 
[16] T. MATSUDA, An inductive proof of a mixed arithmetic-geometric mean inequality, Amer. Math. Monthly 1027 (1995), 634-637.

[17] D. S. MitRINOVIĆ, J. E. PEČARIĆ, AND A. M. FINK, Inequalities involving functions and their integrals and derivatives, Kluwer Academic Publishers, Dordrecht/Boston/London, 1991.

[18] D. S. Mitrinović, J. E. PeČARIĆ, AND A. M. FInK, Classical and new inequalities in analysis, Kluwer Academic Publishers, Dordrecht/Boston/London, 1993.

[19] T. L. NGUYEN AND V. D. L. NGUYEN, The Carleman's inequality for a negative power number, J. Math. Anal. Appl. 259 (2001), 219-225.

[20] T. L. Nguyen, V. D. L. NGUyen, And T. T. V. Nguyen, Note on the Carleman's inequality for a negative power number, JIPAM J. Inequal. Pure Appl. Math. 4 (2003), no. 1, article 2, 6 pp. (electronic)

[21] B. OPIC, A. KufNer, Hardy-type inequalities, Pitman Research Notes in Mathematics Series, Longman Scientific \& Technical, Harlow, 1990.

[22] D. V. Prokhorov, Weighted Hardy's inequalities for negative indices, Publ. Math. 48 (2004), no. 2, 423-443.

[23] D. V. ProKhorov, Weighted inequalities involving Riemann-Liouville and Hardy-type operators, $\mathrm{PhD}$. Thesis 2003:38, Dept. of Math., Luleå Univ. of Technology, Luleå 2003.

[24] C. D. TARnAVAS, D. D. TARnAVAS, An inequality for mixed power means, Math. Inequal. \& Appl. 2, (2) (1999), 175-181.

[25] H. S. WILF, On finite sections of the classical inequalities. Nederl. Akad. Wet. Amsterdam Proc. Ser. A. 65 (1962), 340-342 (= Indagationes Mathematicae 24). 